\title{
USE OF THE ECHO MONITORING SYSTEM FOR EnVironmental Control in Pig Facilities
}

\author{
OCEPEK, M.; BERK, P.; RAKUN, J.; \\ JANZEKOVIC, M. \& SKORJANC, D.
}

Abstract: A total of 240 fattening pigs ([landracexlarge white] $\times$ pietren) housed in a pig research centre (Faculty of Agriculture and Life Science, University of Maribor) were used in a study of the effect of the ECHO monitoring system on controlling the microclimatic condition and gas emission rates in winter and summer. With the monitoring system, we were able to achieve optimal microclimatic conditions for pigs in the growth phase. $\mathrm{NH}_{3}$ concentrations measured during summer reached $10 \pm 2$ ppm. Lower $\mathrm{NH}_{3}$ concentrations were detected during the winter $(5 \pm 1 \mathrm{ppm})$. Although $\mathrm{CO}_{2}$ increased $57 \%$ in winter (1094 ppm) in comparison to summer (476 ppm), recorded values were lower than prescribed by the regulations of Council of Europe $(C E) \quad(\max =3000 \mathrm{ppm})$. Higher values in winter are a result of lower ventilation rate, in order to achieve optimal microclimatic conditions. Similarly, $\mathrm{H}_{2} \mathrm{~S}$ concentration $(0.0$ to $0.1 \mathrm{ppm})$ was below the level of $C E$ regulation and International commission of agriculture engineering (ICAE). This experimental result suggests that with the ECHO monitoring device we are able to control and successfully regulate microclimatic conditions and gas concentrations in pig facilities.

Key words: pigs, microclimatic conditions, gas emissions, monitoring system
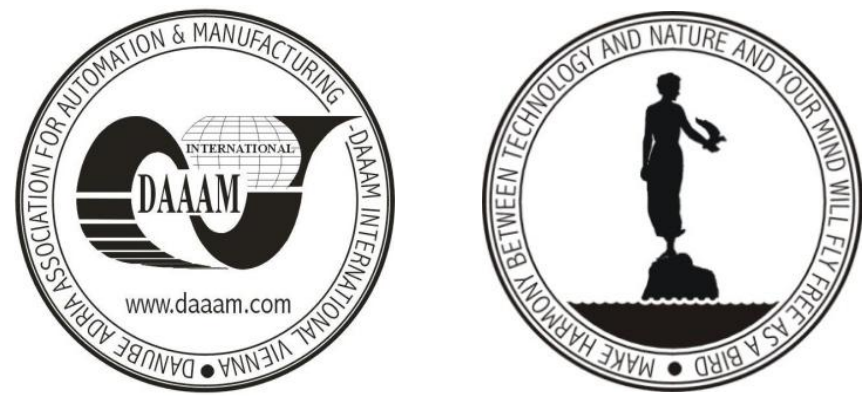

Authors' data: Msc. Ocepek, M[arko]; Bs. Elect. Eng. Berk, P[eter]; Dr. sc. Rakun, J[urij]; Assist. Prof. Janzekovic, M[arjan]; Assoc. Prof. Skorjanc, D[ejan], University of Maribor, Faculty of Agriculture and Life Sciences, Pivola 10, SI-2311, Hoce, Slovenia, marko.ocepek@uni-mb.si,_ peter.berk@uni-mb.si,_ jurij.rakun@uni-mb.si, marjan.janzekovic@uni-mb.si,dejan.skorjanc@uni-mb.si

This Publication has to be referred as: Ocepek, M[arko]; Berk, P[eter]; Janzekovic, M[arjan] \& Skorjanc, D[ejan] (2011). Use of Echo Monitoring System To Control Environment in Pig Facilities, Chapter 43 in DAAAM International Scientific Book 2011, pp. 535-546, B. Katalinic (Ed.), Published by DAAAM International, ISBN 978-3-90150984-1, ISSN 1726-9687, Vienna, Austria

DOI: $10.2507 /$ daaam.scibook.2011.43 


\section{Introduction}

In the past decades pig selection has made great progress in improving pig growth (Cameron, 2003; Gamborg \& Sandøe, 2005), feed conversion efficiency (del Barrio et al., 1993; Berg et al., 2003), carcass and meat quality (Lo Fiego et al., 2004), and fertility characteristics (Tummaruk et al., 2010).

Pig performance is related to appropriate microclimatic conditions (Lebret et al., 2002; Bolhuis et al., 2006; van de Werd \& Day, 2009). Microclimatic characteristics such as ambient temperature, air velocity, relative air humidity and light intensity are closely related to pig fattening performance. Moreover, inadequate air velocity and air gasses negatively affect pig growth rate (Lebret 2008). Similarly, ambient temperature has a strong impact on pig carcass, muscle and adipose tissue characteristics (Lefaucheur at el., 1991; Le Dividich et al., 1998; Lebret et al., 2002). Higher gas concentrations have a negative influence on atmosphere (UNECE, 2007), human health (Urbainet al., 1994), and health of animals (Gerber et al., 1991), and the environment (ICAE, 1984).

It is well known that the season (summer and winter) has an effect on pig growth and fattening. Pig exposure to high summer temperatures is accompanied by lower feed intake and growth performance (Lebret et al., 2002), as well as problems with gilt and sow fertility (Tummaruk et al., 2010). On the contrary, during the winter, no performance or fertility problems were observed, but providing comfortable ambient temperature in pig facilities could be a problem, especially during extremely low environmental temperatures. To solve this problem with microclimatic conditions inside pig facilities, precise and accurate regulation of ambient temperature, air gas concentration and air velocity can be controlled by a microclimatic regulation system (Berk et al., 2010). However, such fully automatic computer systems are expensive and inappropriate for small pig farm units. Nevertheless, cheaper, mobile monitoring systems, which enable monitoring of microclimatic conditions, gas emissions and light intensity may be selected. This information is necessary for breeder decisions about how to adjust microclimatic conditions in pig stalls.

The aim of the present study was to determine whether a mobile monitoring system, ECHO, is suitable for detection and regulation of microclimatic conditions in a small pig farm unit. Therefore, several microclimatic characteristics were determined in winter and summer.

\section{Materials and Methods}

\subsection{Materials}

\subsubsection{Animals}

The study was carried out on 240 pigs (120 per season), in groups of 12 pigs per pen. In both seasons, progeny from LANDRACEXLARGE WHITE dams and PIETRAIN 
sires were used. All pigs were started on the experiment at the age of 71 days and were reared according to conventional practices for housing and feeding pigs (UL. $\mathrm{RS}$, 2007). Initial average body weight of piglets was $25.4 \mathrm{~kg}$ in the summer and $26.8 \mathrm{~kg}$ in the winter. The pigs were fed ad libitum, and their feed intake was measured daily. The experiment lasted for 109 days, until the pigs were 180 days old.

\subsubsection{Experimental design}

The investigation was carried out in the Pig Research Centre, Faculty of Agriculture and Life Science, University of Maribor, Slovenia. Conditions specified for appropriate animal care were followed (UL. RS, 2007). Microclimatic conditions were monitored in the fattening period in different seasons, where the summer period lasted from May to August, 2009, and the winter period from October, 2009, to January, 2010. In the Pig Centre, ten equal pens were used $\left(2.0 \mathrm{~m} \times 2.6 \mathrm{~m}=5.20 \mathrm{~m}^{2}\right)$, with two-thirds of the floor being slatted floor as shown in Fig. 1. The stable was equipped with a negative pressure ventilation system with a diffuse ceiling inlet unit. The system had one central exhaust unit, located at the roof of the house. In such ventilation systems, fresh air came into the attic through the side inlet units and into the room through diffuse ceiling.

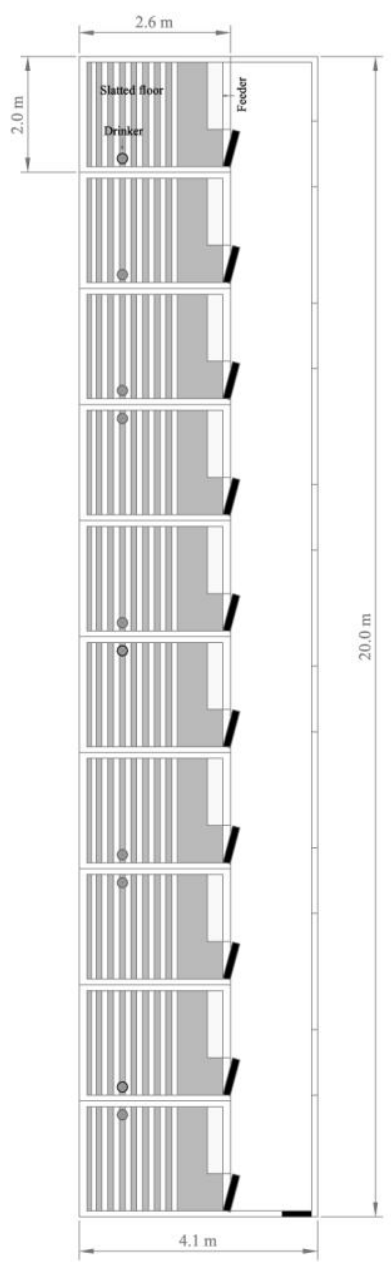

Fig. 1. Layout of the experimental barn 
Ocepek, M.; Berk, P.; Rakun, J.; Janzekovic, M. \& Skorjanc, D.: Use of the Echo...

\subsection{Methods}

\subsubsection{ECHO Monitoring system}

In the present study, the ECHO monitoring system (http://www.echo.si/) was used to measure concentrations of oxygen, ammonia, hydrogen sulphide and carbon dioxide in the air. Additionally, temperature, air velocity and pressure, relative humidity, and light intensity were measured. All values were displayed on the LCD screen on the computer and could, therefore, be controlled directly. All parameters were also stored in an internal hard drive every $5 \mathrm{~min}$ : those values could be transferred through a RS-232 connection to the computer and monitored subsequently (Fig. 2.).

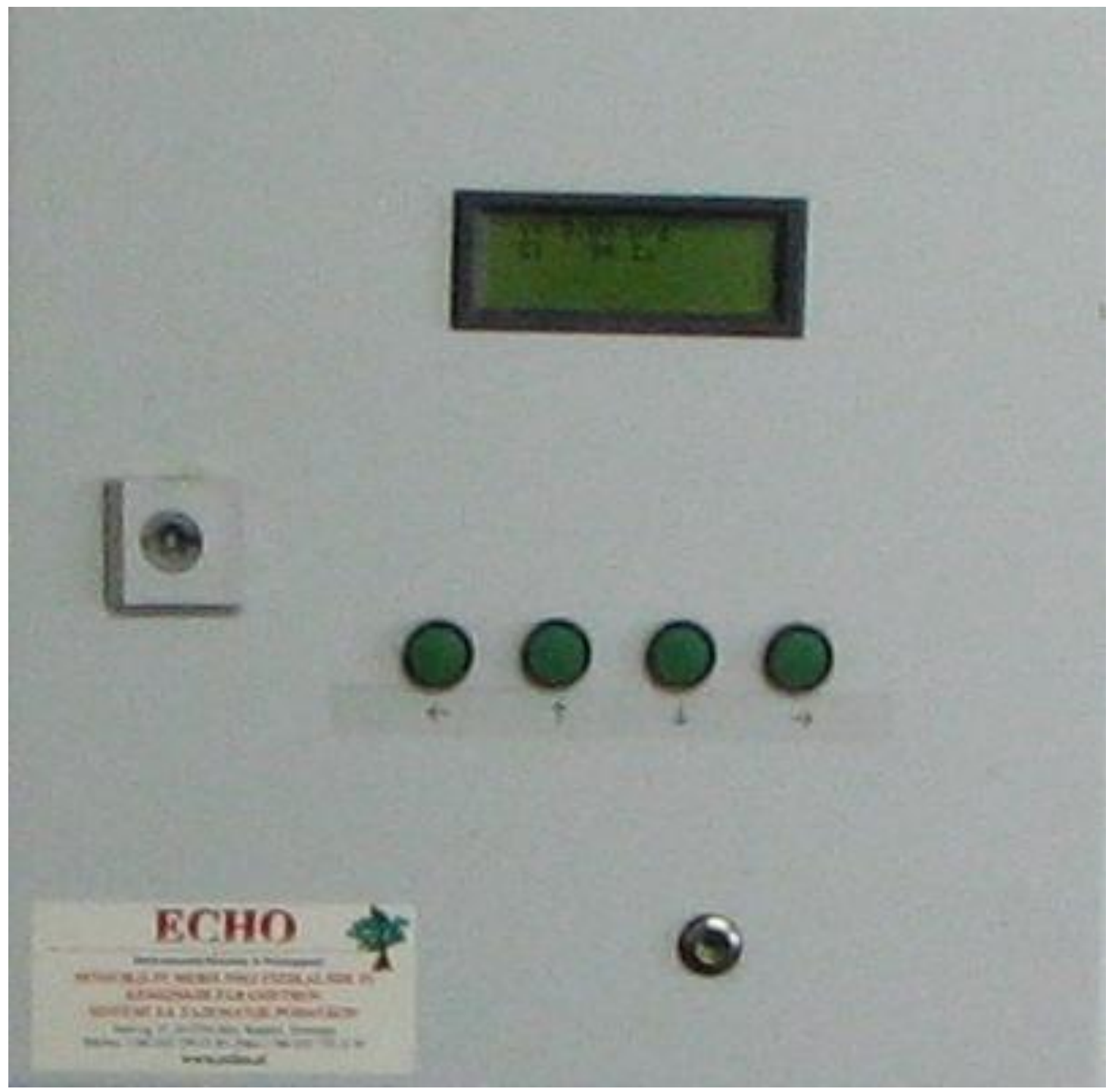

Fig. 2. ECHO monitoring system

\subsubsection{Gases}

The gases (oxygen, ammonia and hydrogen sulfide) were measured using an electrochemical galvanic cell. The measuring ranges were 0-25\%, 0-100 ppm and 0$50 \mathrm{ppm}$ for oxygen, ammonia and hydrogen sulfide, respectively. Measurement accuracy was $0.1 \%$ for oxygen, $1 \mathrm{ppm}$ for ammonia and $0.5 \mathrm{ppm}$ for hydrogen 
sulfide. The level of the gases was determined with a sensor fitted with combined metal-air electrodes. The measurements were taken with porous zinc electrodes and air electrodes. Zinc was used as the anode and active carbon in contact with oxygen from the air was used as the cathode to determine gases. Measured gases from the air reacted when they reached the cathode and formed hydroxyl ions, which migrated into the zinc to form zincate $(\mathrm{Zn}+4 \mathrm{OH}$ ) (as shown in Equation 1). Simultaneously the electrons were released and migrated to the cathode. Eventually, zincate decayed into zinc oxide, and water returned to the electrolyte (Fig. 3). The water and hydroxyls from the anode were recycled at the cathode, so water was not used.

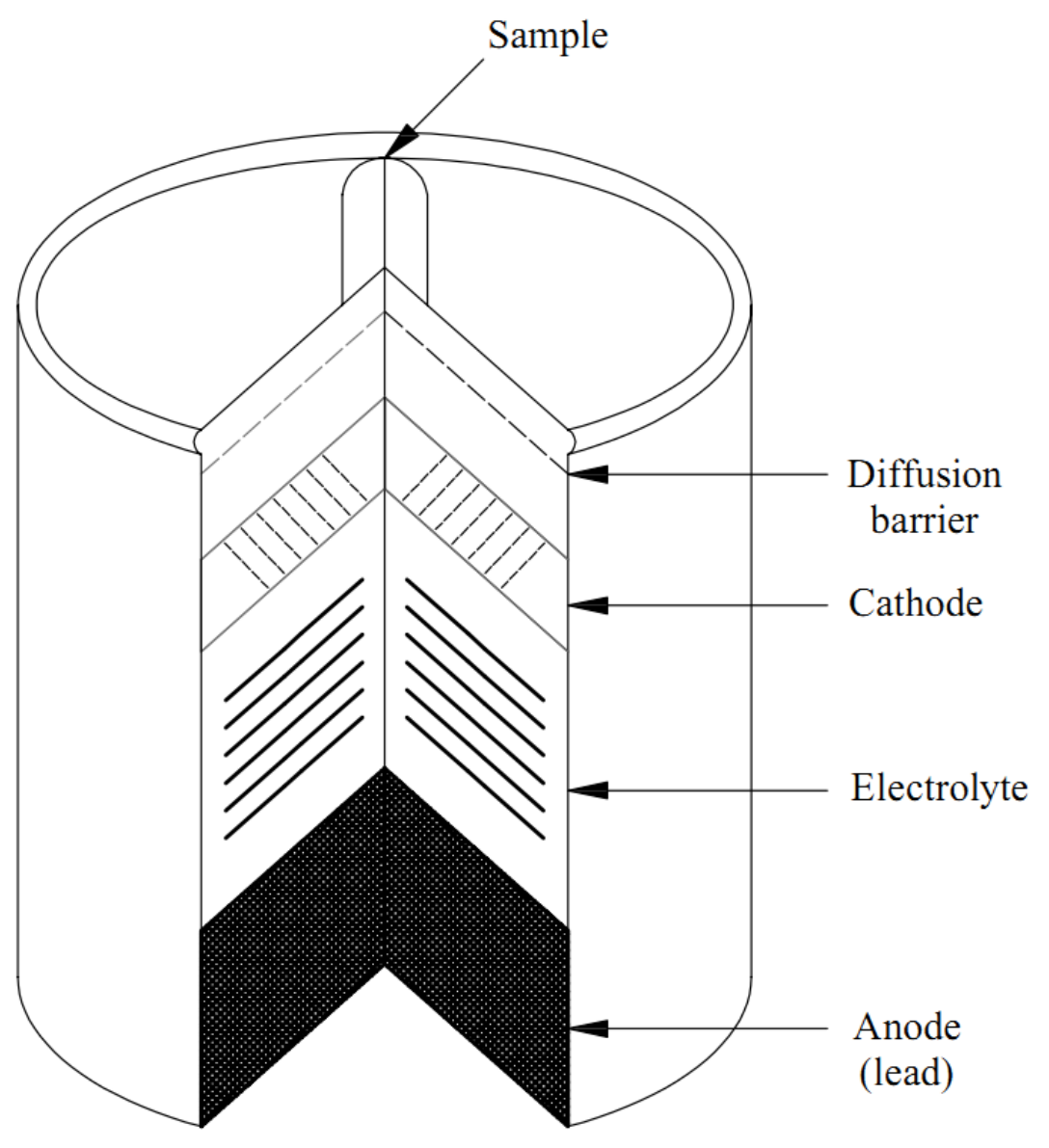

Fig. 3. Sensor for measuring oxygen, ammonia, hydrogen sulphide

Gases were estimated by the following equations:

- Anode reaction:

$$
\mathrm{Zn}+4 \mathrm{OH}^{-}=\mathrm{ZnO}_{2}^{2-}+2 \mathrm{H}_{2} \mathrm{O}+2 \mathrm{e}^{-}
$$

- Cathode reaction:

Acid solution: $\mathrm{O}_{2}+4 \mathrm{H}^{+}+4 \mathrm{e}^{-}=2 \mathrm{H}_{2} \mathrm{O}$

Alkaline solution: $\mathrm{O}_{2}+2 \mathrm{H}_{2} \mathrm{O}+4 \mathrm{e}^{-}=4 \mathrm{OH}$ 
Ocepek, M.; Berk, P.; Rakun, J.; Janzekovic, M. \& Skorjanc, D.: Use of the Echo...

- The overall reaction in alkaline solution can be written as:

$$
2 \mathrm{Zn}+\mathrm{O}_{2}+4 \mathrm{OH}^{-}=2 \mathrm{Zn}_{2}^{2-}+2 \mathrm{H}_{2} \mathrm{O}
$$

Carbon dioxide absorbs energy from the infrared (IR) spectrum (Fig. 4.) Therefore, two dimensional IR gas sensors were used to determine the concentration of carbon dioxide in pig stable air, where an absorption frequency of $4.265 \mu \mathrm{m}$ was used. The measuring range for carbon dioxide was 0-2000 ppm, with a measurement accuracy of $1 \mathrm{ppm}$.

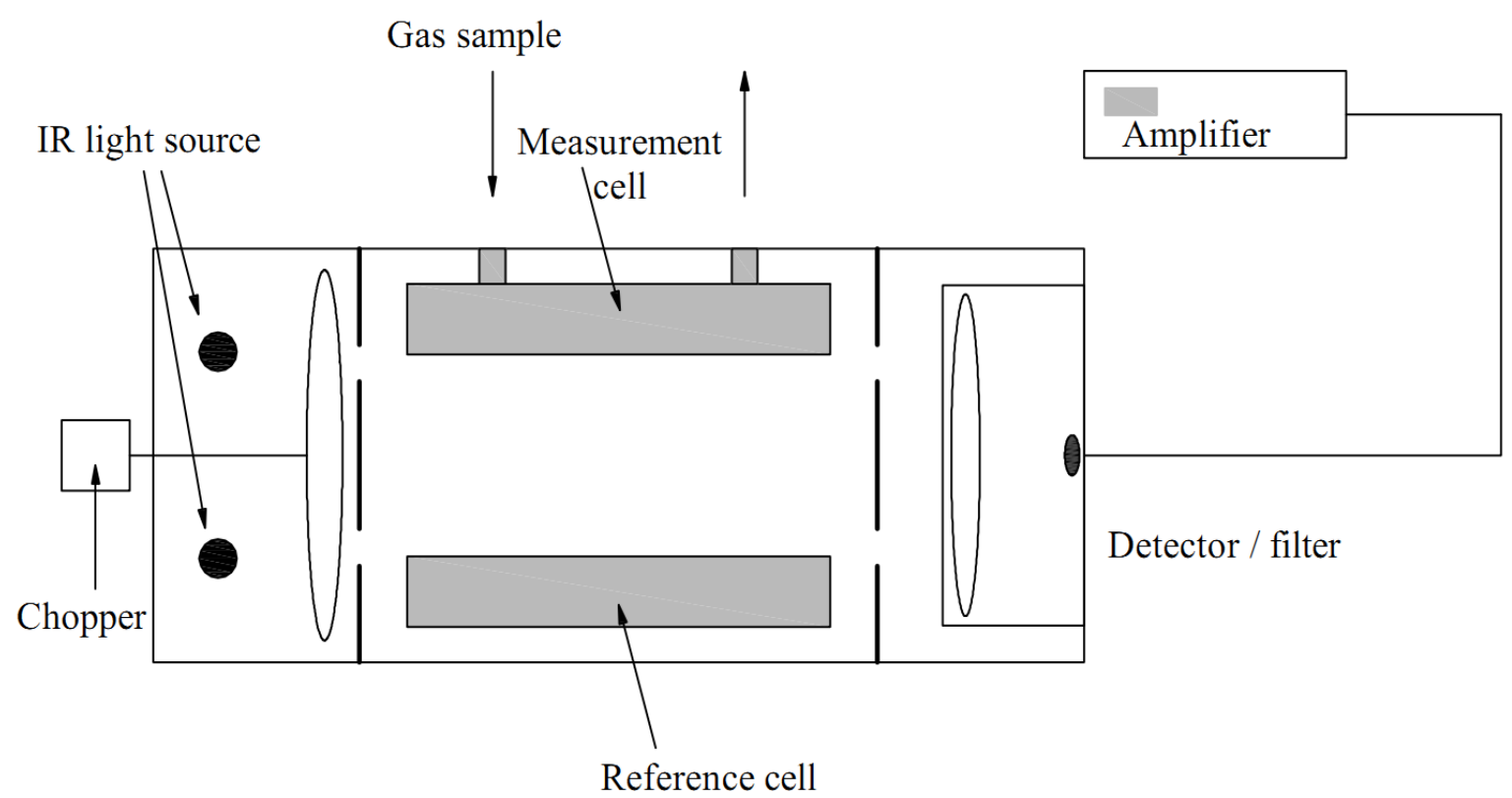

Fig. 4. Sensor for measuring carbon dioxide

\subsubsection{Air velocity, temperature and relative humidity}

Air velocity was measured using a thermal thin-layered detector, which was connected via a 5-meter cable to the detector. The detector could be placed at pig height to measure the airflow. The air velocity measuring range was $0.0-1.0 \mathrm{~m} / \mathrm{s}$, with a measurement accuracy of $0.04 \mathrm{~m} / \mathrm{s}$. Relative humidity was measured using a semiconductor sensor with a measuring range of $0-100 \%$ and accuracy of $\pm 1 \%$. Temperature was measured with resistance thermometers (Pt 100), with a measured range of $-40{ }^{\circ} \mathrm{C}$ to $+60{ }^{\circ} \mathrm{C}$ and accuracy of $1{ }^{\circ} \mathrm{C}$. Sensors for relative humidity and temperature were located in the mid-lower side, while the air velocity detector was situated at the bottom of the machine.

\subsection{Statistical analysis}

The data were analyzed using GLM procedure by SPSS 17 (2008) statistical package. The effect of season was included in the model. Gas concentrations in the pig facility were in terms of standardized conditions of temperature and pressure. Mean ( $\overline{\mathbf{x}})$ values with standard deviations (SD) are presented. 


\section{Results with discussion}

\subsection{Ambient microclimatic conditions}

Microclimatic characteristics that were monitored and controlled throughout the experiment are presented in Table 1 . Our results regarding relative air humidity and light intensity are within ranges specified for appropriate animal care (UL. RS, 2007). Relative humidity was less than the maximum range of $60-80 \%$, and light intensity was above 40 lux. Air velocity in pig buildings is caused by pressure differences, which were caused by sources such as animal heat production, cold structure surfaces, heaters and external wind (Albright, 1990). In accordance with this, we managed to control air velocity in the range of $0.3 \mathrm{~m} / \mathrm{s}$ to $0.7 \mathrm{~m} / \mathrm{s}$, which is within the prescribed norms (Kyriazakis, 1999) for optimal housing conditions. Pigs were able to achieve a daily growth rate of $697 \mathrm{~g}$ in summer and $755 \mathrm{~g}$ in winter (Fig. 5), which were higher than the results presented by Ferguson and Theeruth (2002), where fully controlled systems were used.

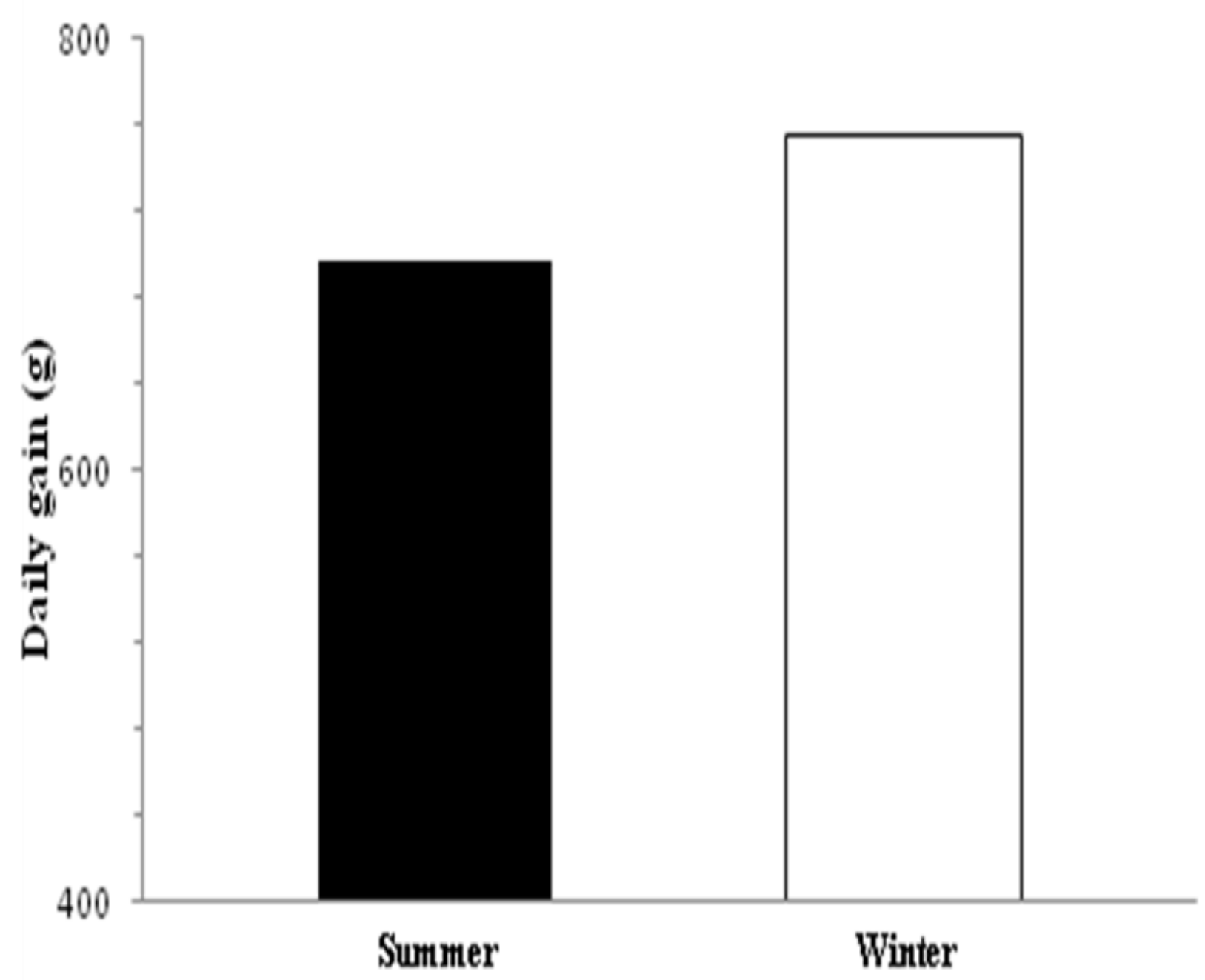

Season

Fig 5. Changes in daily gain for pigs raised in summer and winter period 
Ocepek, M.; Berk, P.; Rakun, J.; Janzekovic, M. \& Skorjanc, D.: Use of the Echo...

$\mathrm{RV}$ - relative humidity; T - temperature; $\mathrm{P}$ - pressure; V - air velocity; $\overline{\mathbf{x}}$ - mean value; SD - standard deviation; $P$ $($ CHARACTERISTICS $\times$ SEASON $)>0.05$.

\begin{tabular}{cccccccc}
\hline & $\begin{array}{c}\text { SUMME } \\
\mathrm{R}\end{array}$ & WINTER & SUMMER & WINTER & SUMMER & WINTER \\
& $\overline{\mathbf{x}}$ & $\overline{\mathbf{x}}$ & \multicolumn{2}{c}{ Min } & \multicolumn{2}{c}{ Max } \\
\hline $\mathrm{RH}(\%)$ & 57.7 & 56.4 & - & 49.3 & 48.6 & 66.4 & 69.6 \\
$\mathrm{~T}\left({ }^{\circ} \mathrm{C}\right)$ & 24.9 & 14.2 & $\mathbf{0 . 0 0 1}$ & 19.0 & 1.5 & 32.5 & 22.5 \\
$\mathrm{P}(\mathrm{bar})$ & 1004 & 979 & - & 1001 & 972 & 1008 & 986 \\
$\mathrm{~V}(\mathrm{~m} / \mathrm{s})$ & 0.7 & 0.3 & - & 0.3 & 0.3 & 1.2 & 0.7 \\
$\mathrm{E}($ Lux $)$ & 47 & 42 & - & 6 & 0 & 154 & 366 \\
\hline
\end{tabular}

Tab. 1. Measured microclimatic condition in summer and winter season

The difference in growth rate between the summer and winter periods can be explained by the ambient temperature. Energy requirements increased as temperature decreased below the critical temperature. On the other hand, ambient temperatures above critical temperatures led to decreased feed intake and growth rate of pigs (Lebret, 2008). From the present study, rearing conditions at temperatures around 15 ${ }^{\circ} \mathrm{C}$ increased growth rate of pigs. A possible explanation for results at this temperature is that pigs have higher voluntary feed intake. These findings are in agreement with previous work of Lebret et al. (2002). Feed intake was higher in winter than in summer $(2.0 \mathrm{~kg}$ vs. $1.5 \mathrm{~kg})$.

\subsection{Observed gas concentrations}

Measured gas emission rates during summer and winter are presented in Table 2. The average $\mathrm{NH}_{3}$ concentration measured was higher during summer than during winter $(10 \pm 2 \mathrm{ppm}$ vs. $5 \pm 1 \mathrm{ppm})$. These experimental results suggest that $\mathrm{NH}_{3}$ emissions are closely related to ambient temperature and ventilation rates. Furthermore, $\mathrm{NH}_{3}$ was obviously influenced $(P<0.001)$ by the season, with typically higher values during the summer and lower values during the winter. These results are in agreement with previous studies where fully controlled systems were used (Aarnink et al., 1997; Harper et al., 2004). That phenomenon can be explained by animal habits. A possible explanation is that pigs during the summer more frequently lay down on the slatted floor and excreted on the solid floor (Fraser, 1985; Aarnink et al., 1997). Consequently, seasonal variations of ammonia emissions rates have to be taken in to account for measurement procedures and determination of annual emission factors (Janzekovic et al., 2004; Philippe et al., 2011). Nevertheless, in both seasons, $\mathrm{NH}_{3}$ emission rates were lower $(\max .=20 \mathrm{ppm})$ than prescribed by $\mathrm{CE}$. 
$\mathrm{O}_{2}$ - oxide; $\mathrm{CO}_{2}$ - carbon dioxide; $\mathrm{H}_{2} \mathrm{~S}$ - hydrogen sulphide; $\mathrm{NH}_{3}$ - ammonia; $\overline{\mathbf{x}}$ - mean value; $\mathrm{SD}$ - standard deviation;

\begin{tabular}{cccccccc}
\hline & $\begin{array}{c}\text { SUMMER } \\
\overline{\mathbf{x}} \pm \mathrm{SD}\end{array}$ & $\begin{array}{c}\text { WINTER } \\
\overline{\mathbf{x}} \pm \mathrm{SD}\end{array}$ & $\mathrm{P}$ & $\begin{array}{r}\text { SUMMER } \\
\text { WINTER }\end{array}$ & SUMMER & WINTER \\
& 18 & 15 & - & 16 & 13 & 18 & 17 \\
$\mathrm{O}_{2}(\%)$ & 476 & 1094 & - & 302 & 247 & 853 & 2035 \\
$\mathrm{CO}_{2}(\mathrm{ppm})$ & 0.1 & 0.0 & - & 0 & 0 & 0.2 & 0.1 \\
$\mathrm{H}_{2} \mathrm{~S}(\mathrm{ppm})$ & $10 \pm 2$ & $5 \pm 1$ & 0.0 & 6 & 1 & 17 & 7 \\
$\mathrm{NH}_{3}(\mathrm{ppm})$ & 10 & & & & & \\
\end{tabular}

$P$ (CHARACTERISTICS $\times$ SEASON $)>0.05$.

Tab. 2. Measured gas emission rate during summer and winter season

The concentration of $\mathrm{CO}_{2}$ is related to the animals' metabolism, and it is an indicator of air quality in buildings/stables (ICAE, 1984).

A major portion of $\mathrm{CO}_{2}$ is produced through respiration (96\%) and only $4 \%$ from the manure system (Ouwerkerk \& van Pedersen, 1994; Stajnko et al., 2009). Depending on the manure system, the proportion of $\mathrm{CO}_{2}$ from manure can account for $10 \%$ (Gerrits et al., 2001) to $35 \%$ of the total (Ni et al., 1999). In the present study, the $\mathrm{CO}_{2}$ concentration in winter was only $57 \%$ as high as it was in summer. These differences resulted due to lower ventilation rate in the winter (Table 2). However, the highest concentration of $\mathrm{CO}_{2}$ presented in this study is in accordance with ICAE standards (3000 ppm). A lower ventilation rate was used on purpose, as optimal rearing conditions were maintained in order to achieve better performance parameters, such as daily gain.

$\mathrm{H}_{2} \mathrm{~S}$ emission is a product of anaerobic breakdown of manure after storing. In the case of insufficient ventilation rate, $\mathrm{H}_{2} \mathrm{~S}$ could be toxic to humans and animals (Patni \& Clarke, 1990). Therefore, according to the CE (1974), the concentration rate of $\mathrm{H}_{2} \mathrm{~S}$ should be lower than $5 \mathrm{ppm}$. The recommended ICAE (1984) concentration for $\mathrm{H}_{2} \mathrm{~S}$ is $0.5 \mathrm{ppm}$. Results from the present study indicate that the concentration of $\mathrm{H}_{2} \mathrm{~S}$ was under that recommended by CE and ICAE.

\section{Conclusions}

The ECHO system was designed for monitoring microclimatic conditions and gas emission rates. With this device we controlled ambient environmental characteristics such as temperature, air velocity, relative humidity, light intensity, and air pressure. Despite maintaining comfortable rearing conditions in pig facilities, we were able to control gas emission without endangering pigs, humans, equipment, and the environment. In the future, ECHO monitoring system could be used as cheap microclimatic monitoring device in comparison with expensive systems that are nowadays available in the market. In addition, monitoring device will be upgrade in 
Ocepek, M.; Berk, P.; Rakun, J.; Janzekovic, M. \& Skorjanc, D.: Use of the Echo...

terms of electronic notifying about when microclimatic conditions are not in prescribed norms.

\section{References}

Aarnink, A. J. A.; Swierstra, D.; van den Berg, A. J. \& Speelman, L. (1997). Effect of type of slatted floor and degree of fouling of solid floor on ammonia emission rates from fattening piggeries. Journal of Agricultural Engineering Research, Vol.66, No.2, pp.93-102, ISSN 1095-9246

Albright, L. D. (1990). Environment Control for Animals and Plants, Asae Publication, ISBN 0929355083, St. Joseph, Michigan, USA

Berg, E. P.; Maddock, K. R. \& Linville, M. L. (2003). Creatine monohydrate supplemented in swine finishing diets and fresh pork quality: III. Evaluating the cumulative effect of creatine monohydrate and alpha-lipoic acid. Journal of Animal Science, Vol.81, No.1, pp.2469-2474, ISSN 1525-3163

Berk, P.; Rakun, J.; Vindis, P.; Stajnko, D. \& Lakota, M. Temperature loop structure with fuzzy and classical controllers. In: DAAAM International scientific book 2010, B Katalinic (Ed.), 117-128, DAAM international ISBN 3-901509-43-7, Vienna

Bolhuis, J. E.; Schouten, W. G. P.; Schrama, J. W. \& Wiegant, V. M. (2006). Effects of rearing and housing environment on behaviour and performance of pigs with different coping characteristics. Applied Animal Behaviour Science, Vol.10, No.1, pp.68-85, ISSN 0168-1591

del Barrio, A. S.; Schrama J. W.; van der Hel, W.; Beltman, H. M. \& Verstegen, M. W. (1993). Energy metabolism of growing pigs after transportation, regrouping, and exposure to new housing conditions as affected by feeding level. Journal of animal science, Vol.71, No.7, pp.1754-1760, ISSN 15253163

CE - Council of Europe (1974). Resolution on the manufacture of detector tubes to control the atmosphere in work places, Council of Europe Publishing, ISBN 978-92-871-5682-2, Belgium

Ferguson, N. S. \& Theeruth, B. K. (2002). Protein and lipid deposition rates in growing pigs following a period of excess fattening. South African Journal of Animal Science, Vol.32, No.2, pp.97-105, ISSN 0375-1589

Fraser, D. (1985). Selection of bedded and unbedded areas by pigs in relation to environmental temperature and behaviour. Applied Animal Behaviour Science, Vol.14, No.2, pp.117-126, ISSN 0375-1589

Gamborg, C. \& Sandøe, P. (2005). Sustainability in farm animal breeding: a review. Livestock Production Science, Vol.92, No.3, pp.221-231, ISSN 0301-6226

Gerber, D. B.; Mancl, K. M.; Veenhuizen, M. A. \& Shurson, G. C. (1991). Ammonia, fcarbon monoxide, carbon dioxide, hydrogen sulfide and methane in swine aconfinement facilities. Compendium on continuing education for the practicing aveterinarian, Vol.13, No.2, pp. 123-133, ISSN 148301488 
Gerrits, W. J. J.; Frijters, K. P. C. M.; van der Linden, J. M.; Heetkamp, M. J. W.; Zandstra, T. \& Schrama, J. W. (2001). Effect of synchronizing dietary protein and glucose supply on nitrogen retention in growing pigs. Journal of Animal Science, Vol.79, No.1, pp.321-328, ISSN 1525-3163

Harper, L. A.; Sharpe, R. R. \& Simmons, J. D. (2004). Ammonia emissions from swine houses in the southeastern United States. Journal of Environmental Quality, Vol.33, No.2, pp.449-457, ISSN 0047-2425

Janzekovic, M.; Mursec, B.; Ploj, A. \& Janzekovic, I. (2004). Machine for liquid manure mixing and aerating. In: DAAM international Scientific book 2004, B Katalinic (Ed.), 189-199, DAAM international, ISBN 3-901509-43-7, Vienna

ICAE-International commission of agriculture engineering. (1984). Climatization of animal houses. Research Centre Bygholm, publisher, ISBN 87-88976-60-2, Denmark

Kyriazakis, I. (1999). A quantitative biology of the pig, Cabi Publishing, ISBN 0851992730, Wallingford, England

Law on Animal Protection. (2007). http://www.uradni-list.si/1/content?id=80271, Uradni list Republike Slovenije no.43/2007, Accesed on 2008-04-26

Lebret, B.; Massabie, P.; Granier, R.; Juin, H.; Mourot, J. \& Chevillon, P. (2002). Influence of outdoor rearing and indoor temperature on growth performance, carcass, adipose tissue and muscle traits in pigs, and on the technological and eating quality of dry-cured hams. Meat Science, Vol.62, No.2, pp.447-455, ISSN 0309-1740

Lebret, B. (2008). Effects of feeding and rearing systems on growth, carcass composition and meat quality in pigs. Animal, Vol.2, No.10, pp.1548-1558, ISSN 1751-7311

Lo Fiego, D. P.; Santoro, P. \& Macchioni, P. (2005). Influence of genetic type, live weight at slaughter and carcass fatness on fatty acid composition of subcutaneous adipose tissue of raw ham in the heavy pig. Meat Science, Vol.69, No.4, pp.107-114, ISSN 0309-1740

Ni, J. Q.; Vinckier, C.; Hendriks, J. \& Coenegrachts, J. (1999). Production of carbon dioxide in a fattening pig house under field conditions. II. Release from the manure. Atmospheric Environment, Vol.33, No. 22, pp.3697-370, ISSN 13522310

Ouwerkerk, E. N. J. \& van Pedersen, S. (1994). Application of the carbon dioxide mass balance method to evaluate ventilation rates in livestock buildings. In: Conference proceedings 1994, J. K. Schueller (Ed.), 516-529, ISBN 19942402341, XII world congress on agricultural engineering, Milano, Italy

Patni, N. K. \& Clarke, S. E. (1990). Transient hazardous conditions in animal buildings due to manure gas released during slurry mixing. In: Agricultural and Food Processing Wastes Proceedings of the Sixth International Symposium 1990, C. L. Peterson (Ed.), 54-65, Proceedings of the sixth 
Ocepek, M.; Berk, P.; Rakun, J.; Janzekovic, M. \& Skorjanc, D.: Use of the Echo...

international symposium on agricultural and food processing wastes, ISBN 0929355105, Chicago, USA

Philippe, F. X.; Cabaraux, J. F. \& Nicks, B. (2011). Ammonia emissions from pig houses: Influencing factors and mitigation techniques. Agriculture, Ecosystems and Environment, Vol.142, No.2, pp.54-70, ISSN 0167-8809

SPSS Version 17.0 for Windows. (2008). Predictive Analytics SoftWare, USA.

Stajnko, D.; Vindis, P. \& Mursec, B. (2009). Reduction of $\mathrm{CO}_{2}$ emission in production of corn in Slovenia. In: DAAAM International scientific book 2009, B Katalinic (Ed.), 573-586, DAAM international, ISBN 3-901509-43-7, Vienna

Tummaruk, P., Tantasuparuk W. \& Techakumphu, M. (2010). Seasonal influences on the litter size at birth of pigs are more pronounced in the gilt than sow litters Source. Journal of Agricultural Science, Vol.148, No.4, pp. 421-432 ISSN 1916-9760

Urbain, B.; Gustin, P.; Prouvost, J.F. \& Ansay, M. (1994). Quantitative assessment of aerial ammonia toxicity to the nasal mucosa by use of the nasal lavage method in pigs, American Journal of Veterinary Research, Vol.55, No.3, pp.64-77, ISSN 133501340

UNECE - United Nations/Economic Commission for Europe. (2007). Strategies and policies for air pollution abatement, United nations publication, ISBN 97892-1-116977-5, Geneva, Switzerland

van de Werd, H. A. \& Day, J. L. D. (2009). A review of environmental enrichment housing systems. Applied Animal Behaviour Science, Vol.116, No.1, pp.1-20, ISSN 0375-1589 